\begin{tabular}{|c|c|c|}
\hline Teologia & Pestroczzonilk \\
\hline Cztowiek & Wydziału Teologicznego UMK \\
$18(2011)$ ISSN 1731-5638
\end{tabular}

FÉLIX MARÍA AROCENA*

PAMPELUNA

\title{
LITURGIA I POSTMODERNIZM W OBLICZU 50. ROCZNICY SOBORU WATYKAŃSKIEGO Il
}

Trzecie tysiąclecie stawia przed Kościołem jedno z najpoważniejszych wyzwań całej jego historii: dokonanie harmonizacji sakralności i antropologii. Tradycyjnie teologia kojarzyła się z obszarem poznania i refleksji wokół wiary, a liturgia aż do nie tak odległych jeszcze czasów, zwykła się była kojarzyć z ceremoniami i przepisami kultu. Dziś wracamy do świadomości, że intellectus fidei jest źródłowo zawsze w relacji do działania liturgicznego Kościoła. Ale gdy już liturgia odzyska swój status teologiczny, trzeba postawić kolejny krok. Polega on na skróceniu dystansu między teologią a liturgią za pomocą teologii wiary celebrowanej, w której przymiotnik 'celebrowanej' określa rzeczownik 'wiary', przedstawiając ją jako tajemnicę boskiej ágape dostrzegalnej w znakach celebracji eklezjalnej: 'wszystko' we 'fragmencie'. To właśnie nazywamy teologią liturgiczna, której dyskurs może dać impuls do głoszenia kerygmy na wymaganych przez postmodernizm współrzędnych myślenia i rozumienia.

* Facultad de Teología, Universidad de Navarra. 


\section{MIĘDZY TEOLOGIĄ LITURGICZNĄ A POST-MODERNIZMEM}

Uprawianie teologii „wiary celebrowanej” oznacza zharmonizowanie symbolu i rozumu, prawdy i piękna, teologii i modlitwy. Zbliżając się do 50. rocznicy Soboru Watykańskiego II jest wskazana nowa refleksja nad liturgią jako źródłowym działaniem symbolicznym. Ta rocznica stanowi również doskonałą okazję, aby podjąć refleksje nad symbolami chrześcijańskimi, którym przysługuje centralne miejsce w katechezie, która siłą rzeczy powinna być coraz bardziej mistagogiczna.

Na kanwie tego pragnienia, nie będzie niczym niewskazanym, aby kultura postmodernistyczna i chrześcijaństwo usiadły do dialogu przy okrągłym stole teologii liturgicznej. Kościół szanujący autentyczny dialog, nie będzie prosić postmodernizm, aby zrezygnował ze swoich przekonań; ze swej strony natomiast postmodernizm wysłucha przekonań Kościoła, a wśród nich tego, że żaden człowiek nie może tworzyć jak to czynili Homer, Sofokles czy Shakespeare, jeśli nie wierzy w nieśmiertelność duszy ludzkiej. Jak mawiał Dawid Herbert Lawrence, trzeba być strasznie religijnym, aby być artystą ${ }^{1}$. Postmodernizm ze swoim pragnieniem piękna prosi chrześcijaństwo o nowy sposób głoszenia Dobrej Nowiny. Językiem nie tylko intelektualnym, lecz również symbolicznym o sile ekspresji piękna jako związanego z dziełem prawdy. Dla Kościoła to ważne zadanie, gdyż to on rodzi zdumienie religijne wobec niewysłowionego Boga, który się objawia. Ale jeśli teologia liturgiczna otwiera niespodziewane możliwości dialogu z kulturą postmodernistyczną, wykopuje głęboką studnię w sercu chrześcijanina, która będzie w stanie dostarczyć wody, potrzebnej po to, aby przejść przez pustynie panującego sekularyzmu i relatywizmu, bez uszczerbku dla swej tożsamości: bycia obrazem i hymnem niepojętego Pana i Świętego.

Liturgia umożliwia cudowny lot do intymnej komunii trynitarnej jedynego Boga $^{2}$. Liturgia nie sprowadza się jedynie do celebracji; cała ona - równocześnie - jest w każdej celebracji³ ${ }^{3}$ Gdyby nas poproszono o wewnętrzne odczytanie celebracji liturgicznej powiedzielibyśmy, że chrześcijańskie ryty są wydarzeniami, które na nowo - w sposób kre-

\footnotetext{
${ }^{1}$ Por. G. Steiner, Presencias reales, Barcelona: Destino, 2002³, s. 275-276.

2 Por. Jan Paweł II, Orientale Lumen 6: „uczestnictwo w życiu trynitarnym urzeczywistnia się poprzez liturgię".

${ }^{3}$ Por. J. Corbon, Liturgia fontal - Misterio, celebración, vida, Palabra, Madrid 2010, s. 260.
} 
atywny i poetycki, osadzony w historii, opowiadają szaleństwo i piękno miłości, którą Bóg nas ukochał dając nam swojego Syna. To, co niewypowiedziane w Bożych tajemnicach objawia się w skromnym blasku liturgii. Nie chodzi w niej o zwykłe uwypuklanie doznań zmysłowych, lecz o zatopienie całego naszego bytu osobowego w przestrzeni piękna, intensywnej światłości, przekraczającego sensu, który wychodzi na nasze spotkanie z wysoka i zaprasza nas, abyśmy w nim uczestniczyli i uczynili czymś swoim ${ }^{4}$. Piękno jest kwiatem, który zakwitł na tym, co prawdziwe i dobre. Gdyby je oddzielić od obu, przypominałoby to próbę oddzielenia promienia światła od latarni, która je wypuszcza. Piękno jest ostatnim słowem, które myślący intelekt może ośmielić się wypowiedzieć, gdyż ono jedynie wieńczy, jak aureola o nieosiągalnym blasku, podwójna gwiazda tego, co prawdziwe i dobre w ich nierozerwalnej relacji. Odwołując się do języka figuratywnego, można byłoby powiedzieć, że piękno jest znakiem quasi-wcielenia Boga w świecie. To, co piękne, jest pozytywnym dowodem na to, że Wcielenie jest możliwe.

W celebracji liturgicznej piękno jest nierozdzielnie związane z prawdą i dobrem. Pomyślmy na przykład, o kielichu używanym do sprawowania Najświętszej Eucharystii: wyróżnia się pięknem, który go wyciąga niejako z codziennej banalności, jaką jest zwykłe picie przy stole. Wystarczy pomyśleć o naszym ludzkim doświadczeniu: gdy wznosimy toast nie bierzemy do ręki zwykłego naczynia, lecz kieliszek, który dobrze zabrzmi, gdy lekko uderzy o inny. Kielich jest wspaniałym naczyniem dla oddania niezwykłego gestu, o wybitnym znaczeniu. Dlatego również calix praeclarus musi być godny, musi przekazywać szacunek, tirom Domini, cześć wobec tego, co zawiera: Krew Pańską. Otwiera się tu przestrzeń dla piękna, dla niezwykłego piękna.

Celebracje chrześcijańskie określa się przez pryzmat słowa, gestu, śpiewu, zapachu, przestrzeni, czasu, porządku, zgromadzenia, posługujących... To symboliczny świat, którego zrozumienie nie powinno stanowić szczególnego problemu dla kobiet i mężczyzn tego pokolenia, gdyż antropologia kulturowa pokazuje nam jak bardzo człowiek jest otwarty na symbol, a teologia potwierdza, że człowiek będąc capa Dei jest także capax symboli. Z tego, że człowiek jest capax Dei wynika, że jest wezwany do osiągnięcia wysokich rzeczy; że jest tak ukierunkowany na Boga, że jego byt jest w istocie zdolnością, pragnieniem oraz wołaniem za

${ }^{4}$ Por. López Quintás, Cuatro filósofos en busca de Dios, Rialp, Madrid 20034, s. 262. 
Bogiem. Naturalna nostalgia została po to pomyślana, aby przygotować nadprzyrodzone podarowanie się Boga $\mathrm{w}$ historii, ku któremu zostało podporządkowane pierwotne stworzenie. Ta kondycja człowieka niesie z sobą bycie także capax symboli z racji samej struktury objawienia i zbawienia. Taki jest właśnie porządek soteriologiczny chciany przez Boga, w którym zbawienie jest działaniem Ojca, objawiającym się w swoim wcielonym Słowie, swoim sakramencie, aby rozciągnąć się - przez powszechny sakrament zbawienia, którym jest Kościół - na sakramenty. W konsekwencji, aby człowiek mógł przyjąć dar zbawienia, potrzebuje struktury ontologicznie otwartej na znak sakramentalny. Jednak doświadczenie pokazuje, że chrześcijanie, przynajmniej ich większość, stają się dziwnymi obserwatorami, którzy kontemplują enigmatyczny przepływ rytów chrześcijańskich w ich świętej samotności. Kluczową zatem sprawą jest wspólnota kultu i symboliczne rozumienie rytu, w którym się uczestniczy. Jeśli wspólnota "nie wchodzi” w język symboliczny, nie będzie trzeba długo czekać na paraliż tych obszarów, które powinny być tryskającym, żywym źródłem.

\section{SYMBOL I TAJEMNICA}

Niektóre z biografii Rafaela († 1520) przekazują, że gdy był młody, otrzymał wewnętrzną wizję piękna Matki Bożej. Jednak żadna kobieta nie odpowiadała temu pięknu przeżytemu przez niego wewnętrznie i dlatego nie mógł ich namalować. Ten stan trwał dość długo aż wreszcie, prawdopodobnie we Florencji ok. 1520 roku, spotkał dziewczynę - la Fornarina - na którą artysta nie patrzył jako na wyraz Madonny, lecz po jej namalowaniu, nastąpiło coś nieoczekiwanego: namalowana forma skłaniała go do przywołania owej wizji wewnętrznej, którą przeżył za swej młodości, tak, iż obraz stał się widzialnym znakiem tego, co niewidzialne. Skąd obraz posiadał taką moc? Z całą pewnością nie z modelu, lecz otrzymał go od artysty: Rafael malując stał się kreatywny.

Przy wszelkich ograniczeniach związanych z przykładami, ten epizod biograficzny Rafaela pomaga lepiej zrozumieć symboliczny świat liturgii. Chrześcijaństwo narodziło się na łonie przymierza, które jako istotowy znak tożsamości ustanowiło absolutny zakaz obrazów ${ }^{5}$.

${ }^{5}$ A. Besançon, L'art et le Christianisme, w: Christianisme - Heritage et destines, C. Michon (ed.), Librairie Général Française, Paris 2002, s. 249. 
Stąd niemożliwość przedstawiania Boga - będącego Miłością i Światłem - usuwa Logos Ojca, przyjmując nasze ciało i postać ludzką, która jest możliwa do oddania. Na bazie tego prawa wcielenia niektóre elementy kosmosu - woda, chleb, olej, wino... - zostały ustanowione przez Chrystusa symbolami boskiego Misterium Światła i Życia. To boski Artysta sam przedstawia swoje własne Misterium; sztukę na sposób boski twórczą, poprzez którą dokonuje się widzialna epifania niewidzialnego Misterium. Tym właśnie jest liturgia: ars Christi. Zostają otwarte w ten sposób dwie zasadnicze kwestie: misterium i jego symbolizacja.

\subsection{MISTERIUM}

Odnośnie pierwszego, niemało było krytyki, którą tajemnica otrzymała ze strony przedstawicieli oświecenia. Dla tych, którzy uznali wcześniejszą od nich filozofię za teologię, tajemnica wzbudza podejrzenia. Tajemna istnieje, twierdzą, ponieważ jeszcze nie odkryliśmy jej racjonalności; istnieje, ponieważ podejmujemy pytania pełne uprzedzeń. Na szczęście dziś, gdy zostały przezwyciężone racjonalistyczne ambicje modernizmu, wiemy, że jeśli nadmierne roszczenie pewności wysusza, o tyle tajemnica zbawia. Misterium nie jest definiowalne ze względu na swoją nadobfitość bytu w relacji do myśli, która pragnęłaby je ująć. Świadomi, że Misterium nie wpisuje się w przestrzeń pojęciową, spróbujemy jednak naszkicować je dzięki kategoriom objawienia Bożego.

Ujmując całościowo, Misterium jest rzeczywistością niewyczerpalną, nigdy nieznaną całkowicie, ze względu na swoje nieskończone bogactwo wewnętrzne. Ale to, co najbardziej właściwe Misterium to nie, jak zwykło się uważać, bycie czymś enigmatycznym. Przeciwnie. W Biblii Misterium to objawienie: Misterium Boga stało się widzialne w Jezusie Chrystusie. Wyróżnikiem Misterium nie jest jego niepoznawalność, lecz bycie przelewającą się sferą sensu, oślepiającym światłem, siłą wywyższającą człowieka, który z wdzięcznością przyjmuje niezmierne możliwości życia, które ofiaruje mu Misterium. Przyjmując je człowiek nabywa pewnej wiedzy i powiększa ją w stopniu, w którym uczestniczy w życiu niosącym z sobą Misterium.

Święty, do którego żaden człowiek nie może się zbliżyć i nie umrzeć, absolutnie Inny, powziął w wieczności tajemniczy projekt stwór- 
czy, odkupieńczy i przebóstwiający człowieka. Ten zamysł zbawczy nabiera ludzkich kształtów w Jezusie Chrystusie, który go realizuje poprzez swoje życie odkupieńcze: w działaniach meandrycznych, których szczyt przyda na paschalne przejście z tego świata do Ojca. To Misterium Chrystusa, które się inkrustuje w historii zbawienia i sprawuje się w liturgii. Misterium, które formują celebracje czyniąc je dostępne zbawczo dla ludzi za pośrednictwem rytów Kościoła.

\subsection{JEGO SYMBOLIZACJA}

W odniesieniu do drugiej kwestii, to znaczy symbolizacji Misterium, wypada przypomnieć, że grecki termin symbolon oznaczał przedmiot podzielony na dwie części. Każda z części, pojedynczo będąca bez wartości, była wręczana każdemu z sygnatariuszy kontraktu. Dopiero poprzez połączenie i zespolenie obu części ów przedmiot odzyskiwał swoją wartość. Grecki czasownik sunballein oznacza jednoczyć, umożliwiać spotkanie między dwoma oddzielonymi elementami, aby mogły odzyskać swoją spójność i sens. Symbol jest więc objawieniem i operująca relacją, uznaniem i przymierzem. Znamienne, że gdy Łukasz pisze na zakończenie perykopy o narodzeniu Jezusa, że "Maria zachowywała wszystkie te sprawy przechowując je w swoim sercu" (Łk 2,19), tłumaczy „przechowywała” przez sunballein. Oznacza to, że Maria pragnęła odnaleźć ich sens: jakie znaczenie i wewnętrzną spójność może mieć ciąg zdarzeń, które przeżywała? Symbole są w jakiejś mierze podobne do przypowieści ewangelicznych.

Autorzy wczesnośredniowieczni, wśród nich Jan Szkot Eriugena (IX w.) podkreślali, że Bóg objawia się zawsze poprzez symbole i metafory, a człowiek powinien przebyć drogę odwrotną: wyjść od wydarzeń oraz rzeczy i tak je interpretować aż dojdzie się do tego, co tajemne i duchowe. Przebywanie tego iter jest naturalne dla człowieka, pragnącego wyrazić to, co niewyrażalne, niejako wychodząc z siebie, przekraczając samego siebie. W Kościele jest to możliwe poprzez działania sakramentalne, zdolne do przedarcia się tam, gdzie kończą się pojęcia i słowa. To działania otwierające, rozszerzające i transcendujące, które kształtują to, co niewypowiadalne, ponieważ znajdują się na granicy czasu i wieczności. Jest uzasadnione, że te działania ogłasza się poprzez twierdzenia dogmatyczne i reguluje normami kanonicznymi. W ten sposób zostają one uchronione przed arbitralnością. Ale same w sobie, działania te są 
nieredukowalne do dogmatów i norm. Misterium to życie i tam, gdzie zachodzi Misterium zaczyna się nowe życie podatne na kształtowanie przez znaki kultyczne. Soborowa konstytucja Sacrosanctum Concilium odwołuje się do tych znaków traktując je jako istotowe elementy przy opisie kultu chrześcijańskiego: w liturgii „przez znaki widzialne wyraża się, i w sposób właściwy poszczególnym znakom urzeczywistnia uświęcenie człowieka, a mistyczne Ciało Jezusa Chrystusa, to jest Głowa ze swymi członkami, wykonuje całkowity kult publiczny" (n. 7).

\section{3. „PER VISIBILIA AD INVISIBILIA”}

Świat symbolu, który jest tak stary jak człowiek, rodzi pytanie: dlaczego symbol tak współgra z chrześcijaństwem? Ze względu na Chrystusa. On jako wcielone Słowo jest sakramentem Ojca. „Filipie, kto mnie widzi, widzi i Ojca" (J 14,9). Ta symboliczność i przekazywalność Chrystusa nie jest rzeczywistością koniunkturalną (przechodnią), lecz konstytutywną. Owo bycie sakramentem (Ur-Sakrament) pochodzi z samej jego ontologii teantropicznej. Tymi słowami opiewa Chrystusa jeden z tropów nieszporów bizantyjskich na święto Przemienienia: Chryste Jezu, [będąc] widzialnością piękna Boga, przebija blask boskości w zmysłowym doświadczeniu człowieczeństwa ${ }^{6}$. Z tej ontologii teantropicznej Zbawiciela pochodzi misteryjny byt Kościoła-Oblubienicy i modalizacja sakramentalna. Te sakramenty są wydarzeniami zbawczymi, których rytualne sprawowanie wprowadza mirabilia Dei do Kościoła w tym ostatnim etapie historii zbawienia, który jest czasem Ducha. Jak świadczą o tym Ojcowie Kościoła, to w celebracjach umożliwia się nam dogłębne przylgnięcie do zbawczego udzielania się Boga dla ludzi.

Kościół był dobrym uczniem boskiej pedagogii, która polega na prowadzeniu człowieka ścieżkami symboli: prowadzenia go za rękę od tego, co widzialne do tego, co niewidzialne, aby w ten sposób osiągnąć to, co transcendentne: per visibilia ad invisibilia. To stwierdzenie, jak wiemy, zajmuje szczególne miejsce w rzymskiej liturgii Bożego Narodzenia; w prefacji Mszału Rzymskiego czytamy: abyśmy poznając Boga

${ }^{6}$ Por. Anthologhion IV, Ant. ai I Vespri Trasfigurazione, 878-879: Cristo Gesù, visibilitŕ della belleza di Dio, ha fatto trasparire lo splendore della divinitŕ nella sperienza sensibile della humanita (cyt. C. Valenziano, La riforma liturgica del Concilio, Bologna 2004, s. 117). 
$\mathrm{w}$ widzialnej postaci, zostali przezeń porwani do umiłowania rzeczy niewidzialnych"7. Ale nie tylko Mszał; już Platon († ok.347 przed Chr.) i Pseudo-Dionizy wyjaśniali, że to, co zmysłowe było odbiciem tego, co intelektualne. $W$ późniejszym czasie niektórzy myśliciele również poszli tą drogą. Blaise Pascal († 1662) zapisze, że każda rzecz skrywa tajemnice, a wszystkie rzeczy są niczym zasłona, która ukrywa Boga. Antoine de Saint Exupéry († 1944) przypomina, że to, co najważniejsze jest niewidzialne dla oczu'. A w ex libris Maurice Blondela († 1949) możemy przeczytać: per ea quć videntur et absunt, ad ea quć non videntur et sunt (poprzez to, co się widzi i brakuje do tego, co nie widzi się i są).

Paleochrześcijańska sztuka malarska i później sztuka romańska były dobrymi odbiorcami tej linii symbolicznej. Począwszy od malowideł w rzymskich katakumbach, przez motywy przedstawiane w domu Dura-Europos (Mezopotamia, III w.), aż po maiestas Chrystusa ukrzyżowanego i ubranego w szaty kapłańskie w sztuce romańskiej... bardziej niż opowiadać epopeje są znakami, które przywołują na drodze symbolicznej to, wszystko co kult chrześcijański obwieszcza, aktualizuje i przekazuje sakramentalnie: misterium zbawienia ${ }^{9}$. Wśród tych znaków są Dawid i Goliat, Konasz, Daniel pośród lwów; Piotr ocalony od morza, Dobry Pasterz, wskrzeszenie Łazarza, rozmnożenie chlebów...

Istotnie, jest cennym darem odziedziczenie mentalności zwracającej uwagę na czystość praxix kultycznego, czujnej nie tylko na ortodoksję słów sakramentalnych, lecz również ortodoksję gestów Chrystusa. Pozbawiać się jej byłoby niewiernością wobec Pana i Jego Kościoła. Jednocześnie cierpiałby na krótkowzroczność ten, kto rozumiałby chrześcijaństwo jako fałszywą gnosis, abstrakcyjną i pojęciową. Objawienie Boże otwiera przed nami dużo szerszy horyzont. Język werbalny nie jest jedynym językiem objawienia, podobnie jak matka nie tuli swojego dziecka tylko i wyłącznie za pomocą swoich słów, lecz poprzez różnorodną gamę kodów komunikacji. W komunikacji liturgicznej języki niewerbalne przekazują napięcie tak wielkie jak języki werbalne. Przesadne wartościowanie tego, co pojęciowe i racjonalne w przekazie ustępuje miejsca rozwinięciu całej ludzkiej ekspresyjności i wówczas ochrzczony czuje się pociągnięty we

7 Por. Had 38 i 51; Pad 6.

${ }^{8}$ Por. A. de Saint Exupéry, Le Petit Prince, Gallimard, Paris 1946, s. 72: on ne voit bien qu'avec le cour. L'essentiel est invisible pour les yeux.

${ }^{9}$ Por. B. Neunheuser, Storia della liturgia attraverso le epoche culturali, Edizioni Liturgiche, Roma 1977, s. 34-38. 
wszystkich możliwych wymiarach swojej zmysłowości przez wciągającą go celebrację. W niej ciężar prawdy znaczenia poznaje się na drodze fascynacji znaczącego ${ }^{10}$.

\section{WIGOR SYMBOLICZNO-SAKRAMENTALNY CELEBRACJI}

Utrzymywanie konnaturalności z wigorem symbolicznym liturgii jest dziedzictwem chrześcijaństwa. Byli jednak tacy, którzy chcieli odkryć racje utylitarne we wszystkich rytach. Zasłynął w tym względzie Claude De Vert († 1708), dla którego wszystkie ryty miały swoją motywację praktyczną: jeśli w czasie Mszy zapalano świece, to dlatego, że w katakumbach panowały ciemności; jeśli stosowano kadzidło to po to, aby usunąć brzydkie zapachy z pomieszczeń bez wentylacji; jeśli neofici nosili zapalone świece w swoich rękach po chrzcie, to dlatego, że sprawowano chrzest w noc paschalną, w której trzeba było oświecić drogę prowadzącą od baptysterium do ołtarza. Ale jak reagował już w tamtym czasie Pierre Le Brun († 1729), jeśli te ryty były wykonywane jedynie ze względu utylitarnych, nie jest zrozumiałym dlaczego biskup, a nie diakon, okadzał ołtarz; ani dlaczego katechumeni, którzy potrzebowali świece, aby oświetlić drogę od baptysterium do ołtarza, nie potrzebowali tychże świec wcześniej, kierując się z kościoła do baptysterium; albo dlaczego nie dotyczyło to biskupa i pozostałych wiernych. Gdy prowadzimy rozmowę na temat znaków liturgicznych często ktoś stwierdza: ale jakie ma to znaczenie? Ogólnie rzecz biorąc, ktoś, kto wypowiada się w ten sposób, wyrobił swoje przekonanie na podstawie tego, co widział. A jeśli widział niedbale wykonywane znaki, mało ekspresyjne, wówczas jego wrażliwość na sakramentalność będzie relatywnie niska. W świecie symboliki liturgicznej nie ma jednak nic nieznaczącego. Do tego stopnia jest tego świadomy bizantyjski eparcha, iż nigdy nie rozpoczyna Boskiej Liturgii, aż nie sprawdzi, że wszystkie elementy i przedmioty przeznaczone do udziału w bliskiej już celebracji, zostały rozłożone zarówno w prosphora i na ołtarzu sanktuarium, a także po drugiej stronie ikonostazu i są doskonale przygotowane $\mathrm{w}$ zgodzie $\mathrm{z}$ szacownymi zwyczajami swojej tradycji rytualnej.

${ }^{10}$ Por. G. Bonaccorso, La dimensione comunicativa della liturgia, "Rassegna di Teologia" 41 (2000) 495. 
Aby zatem wejść w liturgię wymaga się pewnych konkretnych postaw. Jedną z nich i nie ostatnią, jest szacunek dla pokornych zasłon, za którymi Pan odsłania i ukrywa swoją obecność. Tymi 'zasłonami' są znaki sakramentalne liturgii. Dla francuskiego myśliciela Błażeja Pascala († 1662) ten, który wstydził się "sakramentów pokory Słowa" wydawał się godny wielkiej zbrodni, jak początkowo działo się w życiu św. Augustyna, który wyznawał: „,ale ja nie byłem pokornym, nie uznawałem pokornego Jezusa za mojego Boga, ani nie wiedziałem czego mogła mnie nauczyć Jego słabość"11.

W zgodzie ze swoim charakterem symbolicznym, Kościół sprawuje dary Boże z wielkim bogactwem kodów lingwistycznych, ponieważ w pragnieniu opowiedzenia Misterium, języki się nie wykluczają, lecz wzajemnie uzupełniają. Kościół potrafi wyczuć, kiedy jest odpowiednia chwila na słowo, kiedy na gest, kiedy na sztukę ${ }^{12}$. W konsekwencji każda celebracja wyraża się poprzez swoistą gramatykę symboli skierowanych nie tylko do jednego wymiaru naszej osoby, ale do niej samej w jej całości. Przyjrzyjmy się kilku przykładom:

W sakramencie małżeństwa, dzięki zastosowaniu symbolicznego języka miłości i przymierza możemy wniknąć w dużo głębszy poziom rozumienia małżeństwa niż zwykła umowa. W celebracji tego sakramentu pojawiają się obrączki, welony, kolory, gesty, śpiewy... nośniki przeznaczone do wyciśnięcia silnego ładunku impresyjnego na nasze zmysły, które teologia liturgiczna uznaje za centra odbiorcze treści wiary.

Dla Izydora z Sewilli († 636), siedem lamp zawieszonych nad oftarzem do sprawowania liturgii $\mathrm{w}$ rycie hiszpańskim symbolizuje siedem darów Ducha Świętego i siedem kościołów, które wspomina 'Widzący” w swoim Objawieniu. Poprzez tę symbolikę wierni postrzegają Eucharystię jako boską i eklezjalną 'synergię'.

Cześć, którą oddają mnisi, śpiewając doksoloię kończącą psalmy z Liturgii Godzin jest językiem symbolicznym, który zaprasza nas do wejścia $\mathrm{w}$ komunię $\mathrm{z}$ tajemnicą paschalną Jezusa. Ten język zakłada dwa ruchy: schylenie się i ponowne podniesienie przypominające zanurzenie katechumenów w wodach chrzcielnych i ich wyjście z sadzawki chrzcielnej; jest symbolem uniżenia Chrystusa aż do śmierci krzyżowej i Jego chwalebnego wywyższenia.

${ }^{11}$ Por. B. Pascal, Pensées, en M. L. Brunschvig (ed.), Hachette, Paris 1960, s. 679,.683; por. Agustín de Hipona, Confessiones, VII, 18, 24, Madrid: BAC 11, s. 478.

${ }^{12}$ Por. O. Clèment, M. I. Rupnik, Anche se muore vivrà - Saggio sulla resurrezione dei corpi, Lipa, Roma 2003, s. 8. 
Trzecie wydanie typiczne Ogólnego Wprowadzenia do Mszału Rzymskiego podobnie wyjaśnia symbolikę przebijającą z wielu gestów wykonywanych $\mathrm{w}$ trakcie celebracji eucharystycznej: uklęknięcie, schylenie głowy, okadzanie, commixtio, dlaczego powinien być tylko jeden ołtarz... czego tak często nie wspominały poprzednie wydania.

Głos liturgiczny Kościoła wyraża się za pomocą inwokacji, wstawiennictwa, doksologii... Jest to język modlitwy, zdolny do przekazania rzeczywistości łaski, otwarty zawsze na nowe rozumienia. W odróżnieniu od analitycznego i precyzyjnego języka teologii systematycznej, teksty liturgiczne posługują się językiem sugestywnym i syntetycznym. Modlący się głos Oblubienicy, z całą swoją wyjątkowością, prosi o "zstąpienie" prawd objawionych, uchwyconych przez wiarę, począwszy od ich przyjęcia naturalnego, którym jest rozumienie aż do serca, aby gdy już się tam znajda, otrzymały życie. Przeglądając stronice jakiejkolwiek księgi liturgicznej mamy wrażenie, że ze zwykłej prozy niejako emanuje kwiat myśli, modlitwy, jakbyśmy asystowali przy zwycięstwie ducha nad literą: każda z formuł jest oknem ku Tajemnicy.

Ale, aby było czytelne to odwołanie sprawiane przez ryty do owego większego znaczenia, którym jest łaska (res sacramenti), zostają ustalane pewne celebracje, które promieniują prawdą i prostota, autentycznością i godnością. To, co w nich się dokonuje nie może być prozaiczne ani wystawne, ani banalne, lecz czyste, szlachetne i w dobrym guście. Są to właściwości języka, którym Kościół oddaje wewnętrzny hołd Chrystusowi, swój szacunek do tego, co sprawuje. A sprawuje misterium Chrystusa poprzez symbole i gesty, które uobecniając soteriologię Pośrednika, pozwalają nam nią żyć, pośród tajemniczej współczesności wobec wydarzeń zbawczych.

Człowiek współczesny posiada zazwyczaj wrażliwość bardziej ukierunkowaną na skromność i prostotę niż na to, co barokowe i ostentacyjne. Jeśli jakaś celebracja nie wydaje mu się „właściwa” (rozumiejąc tutaj termin 'grata' nie z punktu widzenia subiektywnych gustów, lecz obiektywnie z perspektywy antropologicznej, to znaczy, jako działanie empatyczne wobec najintymniejszego konstytuwnego centrum osoby ludzkiej), to dlatego, że nie jest nasycona ars celebrandi. Na wejście każda celebracja liturgiczna jest, powiedzmy to w ten sposób, 'miła'; w przeciwnym przypadku należałoby rozpocząc od zrewidowania ars celebrandi tego, który przewodniczy celebracji. Wspomniana ars celebrandi pochodzi z ścisłego posłuszeństwa normom liturygicznym w ich pełni. Ars celebrandi oznacza sprawowanie actus celebrationis będącego wewnętrzną epifanią misterium. Ars celebrandi jest wyrazem drogi wiary, która podąża za duchem tego, 
który prowadzi celebrację. Pobudza do wspólnoty wszystkich obecnych z Panem poprzez subtelne zaproszenia, które otrzymuje zgromadzenie i ich potrzebuje. Pomaga w tym, aby za pośrednictwem rytów i modlitwy, zgromadzenie zostało ogarnięte i wewnętrznie napełnione przez Misterium. W pewnym sensie przyszłość liturgii i uczestnictwa w niej chrześcijan rozstrzyga się $\mathrm{w}$ tej sztuce celebracji, zdolnej do przyciągnięcia osób, wierzących bądz nie, siłą prawdy i kusząc pięknem boskości. Ars celebrandi jest sekretem celebracji, która dosięga zbawczo osoby w jej największych aspiracjach.

W perspektywie tego, co do tej pory przedstawiono, zatrzymamy się teraz na symbolice jednego z elementów kosmicznych, którego obecność kształtuje i nasyca wszystkie ryty chrześcijańskie: mam na myśli światło, a w konsekwencji kolory. Światło mocno oddziałuje na architektów i przyczynia się do twórczych rozwiązań u tych, którzy projektują przestrzenie do celebracji, jak dawniej, gdy ustawienie rozet i witraży w średniowiecznych katedrach wymagało uwagi ich budowniczych.

\section{4. ŚWIATŁO I KOLORY}

W starożytności postrzegano ciemność nocy jako rzeczywistość złowrogą. Zapalony pośrodku nocy płomień obdarzał ciepłem i opieką przed niewidzialnymi niebezpieczeństwami. Pierwsze lampy były bardzo proste: płonące kawałki drewna, a w krajach, w których rosła oliwka, niewielkie, gliniane naczynia zawierające olej z zanurzonym w nim knotem. Ale poza swoją przydatnością w życiu codziennymi lampy te posiadały także znaczenie religijne: kto jest zdolny do wyrażenia tego wszystkiego, co przekazuje zapalona lampa przed świętym obrazem? Wejście imperatorów czy dygnitarzy starożytnych poprzedzały lampy, których liczba była proporcjonalna do ich rangi. Pogańskie świątynie, nie wykluczając jerozolimskiej, były oświetlone w ciągu nocy wielką liczbą lamp. Dla Greków i Rzymian, sam akt zapalenia świateł w ich własnych domostwach był wydarzeniem pełnym wymiaru religijnego.

\subsection{BÓG JEST ŚWIATŁOŚCIĄ}

Bóg jest Światłością i nie ma w Nim żadnej ciemności (1 J 1, 5). W Biblii to sam Bóg stosuje do siebie samego język światła, które 
On sam stworzył przez swoje wszechmocne słowo ${ }^{13}$. Bóg promieniuje prawdą niczym promienie światła. Jak oczy widzą światło i przez nie jednoczą się z płomieniem, tak człowiek przyjmuje w sobie prawdę i przez nią jednoczy się z Bogiem. Jak z płomienia odrywa się niejako ciepło, tak z Boga wypływa Jego philantropia. Kto kocha Boga staje się jednym z Nim w miłości, tak jak twarz i ręce stają się jednym z płomieniem, otrzymując jej ciepłą czułość. Jednakże podobnie jak płomień pozostaje sam w sobie nietknięty, czysty i szlachetny, tak również Bóg, który zamieszkuje światłość niedostępną. Spojrzenie wiary odkrywa, od najodleglejszych okresów historii ludzkości, ogromny wysiłek Ducha stwarzającego, ukierunkowanego ku Światłu, które później będzie musiało się objawić. W tajemnicy Trójcy i Jej jedności Bóg przemierza wieczność, aby wejść w czas poprzez misję Syna i Ducha. Jest to czas obietnic, który ustąpi jedynie wobec pełni czasu, gdy zgaśnie lampa Jana Chrzciciela: zapowiedź ustępuje miejsca rzeczywistości, Słowo-Światło zapuszcza swe korzenie w ciele w Nazarecie. W ten sposób Maryja, przyjmując swoje boskie macierzyństwo staje się Niosącą Światło. W najkrótszym dniu roku, gdy słońce świeci najmniej godzin, Kościół wzywa Chrystusa jako „Słońce, które rodzi się z wysoka"14. Kiedy Chrystus był ofiarowany w Świątyni, został nazwany przez starca Symeona "Światłem narodów” (Łk 2, 32): światłem, dzięki któremu wszystko nabiera sensu i w którym wszystko ma swoje miejsce. To w czasie Bożego Narodzenia, natomiast w czasie działalności publicznej Światło zmierza się z ciemnościami, które ostatecznie zwyciężają w popołudnie Wielkiego Piątku. Dokonuje się kenosis Światła, apogeum ciemności, czas Męki. Jednak w niedzielny świt, światło najświetlistszego dnia ze wszystkich dni zwycięża nad ciemnością Złego. Jest to Pascha, niedziela, która stoi u podstaw wszystkich niedziel. Ludzkość, mając zapalone lampy wiary, będzie oczekiwała Sędziego, który napełni światłością nowe niebo i nową ziemię. On jest phos hilaron, „radosnym Światłem świętej chwały Ojca Niebieskiego, Jezusa Chrystusa", jak śpiewały pierwsze pokolenia chrześcijan w hymnie znanym już św. Bazylemu ${ }^{15}$. Jest to parousia lub czas adwentu.

Z wody i Ducha Świętego rodzą się chrześcijanie - ci, którzy są oświeceni przez światło (photismoi) w odnawiającej kąpieli chrzcielnej. Ci, którzy dawniej byli ciemnością, teraz są światłem w Panu, aby kroczyć

\footnotetext{
13 Por. nota de la Biblia de Jerusalén en Io 8, 12.

${ }^{14}$ Liturgia Horarum, 21 decembris, ant. ad Magnificat.

15 Por. Basilio Magno, De Spiritu Sancto, 27, 72, en PG 32, 205.
} 
jako synowie światłości. Światło oblicza Pańskiego odciska się na twarzy człowieka, aby była ona żywym odbiciem jego duszy ${ }^{16}$. A Maryja - jak śpiewa Kościół w czasie Komplety - jest Bramą, która otwarłszy się otwiera dostęp dla Chrystusa - Światła, Sol salutis ${ }^{17}$. Jak księżyc odbija światło słońca, tak Kościół otrzymał misję oświecania wszystkich ludzki odbijając światło swojego Oblubieńca.

\subsection{LITURGIA ŚWIATŁA}

Światło jest cieniem Boga, zasadą zdolną do odkupienia materii z jej ciężkości i nieprzenikalności. Władimir Sołowiow († 1900) postrzega światło jako pierwszą zasadę jedności między tym, co materialne i tym, co niematerialne. Piękno to materia oświecona lub światło wcielone ${ }^{18}$. Co czyni pięknym diament? Jego skład chemiczny jest taki sam jak bazaltu; dlatego to nie sama materia decyduje o jego pięknie. Diament jest piękny dzięki grze łamiących się promieni światła całkowicie złączonych z materią. Promieni, które objawiają się jako świetliste oblicza doskonałej piękności. W tej nierozdzielnej i niezmieszanej fuzji materii i światła każde z nich zachowuje swoje właściwości i nie widzimy ich osobno; podziwia się jedynie oświetlony węgiel czy łuk tęczy.

Światło jest zatem rzeczywistością, która wiele mówi o sakramentalności, ponieważ ostatecznie sakrament jest gwarancją, że to, co boskie wpisało się w to, co ludzkie, a to, co zmysłowe czyni przeźroczystym to, co duchowe ${ }^{19}$. Nic zatem dziwnego, że dla liturgii chrześcijańskiej światło jest terminem pełnym prestiżu właściwym dla słów-talizmanów.

Choć fascynujące znaczenie światła w rytach chrześcijańskich przejawia się w wielu momentach roku liturgicznego, jak na przykład w święcie Ofiarowania Pańskiego, to jednak zwłaszcza w celebracji świętej

${ }^{16}$ Por. Hymn En dies dominica, przypisywany Tomaszowi de Kempis († 1471), w: G. M. Dreves, Analecta hymnica Medii ćvi, Minerva G.m.b.H., Frankfurt a. Main 1887-1961, vol. 48, s. 482-484: est lumen vultus Domini suo impressum vultui, mentis ut sit effigies viva hominis facies.

${ }^{17}$ Liturgia Horarum, Ad Completorium, ant. Ave regina cćlorum, vv. 3-4: salve, Porta, ex qua mundo Lux est orta.

${ }^{18}$ Por. V. Soloviev, Il significato dell'amore e altri scritti, Milano: La Casa di Matriona, 1983, s. 181.

${ }^{19}$ Por. J. Ratzinger, Il fondamento sacramentale dell'esistenza cristiana, Brescia: Queriniana 2005, s. 20-21. 
nocy paschalnej osiąga swój szczyt oraz w Liturgii Godzin, gdzie nigdy się nie kończy.

Uroczysta Wigilia Paschalna rozpoczyna się w ciemnościach nocy. Zgromadzenie asystuje przy narodzinach nowego ognia (podczas tej nocy wszystko jest nowe) który zapala się dzięki iskrze wykrzesanej ze skały, znaku Chrystusa, który w swoim Zmartwychwstaniu sprawia, że ciemny grób wykuty w skale rozbłyska światłem. Od tego nowego ognia zapala się paschał, smukły i niemożliwy do pomylenia z inną świecą. Na jego krańcu znajduje się płomień, poprzez który paschał zamienia swoją oryginalną substancję w promieniujące światło. Wszyscy idą za nim w procesji śpiewając trzykrotnie „Światło Chrystusa”. Podczas procesji chrześcijanie zapalają od tego paschału swoje świece: symbol personalizuje się. A cały kościół zostaje przepełniony w końcu światłem.

Oficium brewiarzowe - celebracja światła, które się rodzi (Jutrznia) i które umiera (Nieszpory) - jest znakiem realizującym modlitewny wymiar tajemnicy paschalnej. Światło jest materia, a wychwalanie kształtuje tę rzeczywistość sakramentalną, którą nazywamy Liturgią Godzin. Sprawowanie Nieszporów w starożytnej liturgii hiszpańskiej zaczynało się właśnie od rytu nazywanego oblatio luminis: gdy zapalono już paschał diakon unosił go nad ołtarzem, w postawie ofiarowania go Bogu i wypowiadał aklamację: „W imię naszego Pana Jezusa Chrystusa, światło i pokój”, na co wierni odpowiadali: "Bogu niech będą dzięki”20. Rozumieli, że ofiarować świecę oznacza ofiarować samego siebie ${ }^{21}$.

\section{3. ŚWIATKO W PRZESTRZENI LITURGICZNEJ}

Przypisuje się Proklosowi († 485) zdanie, że przestrzeń jest najsubtelniejszym ze świateł ${ }^{22}$. Dlatego przestrzeń i światło są w pewien sposób materią pierwszą architektury. Architekt jest świadomy, że projektowanie oznacza przewodzenie światła przez pewną przestrzeń i nie zapomina, że światło cieszy się nadzwyczajną siłą ekspresji ${ }^{23}$. Światło jest pierwszą z konstytutywnych właściwości budynku liturgicznego. Thomas S. Eliot († 1965) mówił o kościołach katolickich, że są “widzialnym przypomnie-

${ }^{20}$ Por. J. Pinell, Las oraciones vespertinas y matutinas de los Domingos de cotidiano en el antiguo rito hispánico, "Ephemerides Liturgicae" 108 (1994) n. 42.

${ }^{21}$ Por. J. Servier, L'homme et l'invisible, Du Rocher, Paris 1964, s. 73.

${ }^{22}$ Por. C. Valenziano, Architetti di chiese, Bologna: Dehoniane, 2005, s. 9.

${ }^{23} \mathrm{~W}$ języku greckim phos (światło) y phemi (mówię) mają ten sam rdzeń (pha-). 
niem o niewidzialnym Świetle". Trzeba na nie spoglądać nade wszystko sub specie lucis ${ }^{24}$.

Starożytne budynki przeznaczone do kultu chrześcijańskiego zawsze cechowała obfitość światła: wskazują na to liczne świadectwa począwszy od Egerii, która uczestniczy w nieszporach sprawowanych przez biskupa w Anástasis Jerozolimskiej, gdzie świece tworzą światło jakby nieskończone, aż po Liber Pontificialis, który przekazuje liczbę zapalanych świec na świecznikach w bazylice laterańskiej w Rzymie: $8370^{25}$. Sto świeczników z brązu, które dziś znajdują się przed ołtarzem konfesji w bazylice św. Piotra są jedynie skromnym śladem wielkiej, pierwotnej iluminacji. W klasztorach monastycznej republiki Góry Atos światła pochodzą z tysięcy małych świeczek, których podnoszenie, opuszczanie i poruszanie stanowi części rytu. W każdym katholikón zwisa z centralnej kopuły, podtrzymywany przez długie łańcuchy świecznik z dachem w formie królewskiej korony, o obwodzie zbliżonym do samej kopuły. Korona jest $\mathrm{z}$ brązu i jest przeplatana świecami i ikonami. Schodzi bardzo nisko, ocierając się niemal o ikonostaz. Inne lampy ze złotego sufitu schodzą ze sklepień transeptów. Podczas uroczystych celebracji w klasztorach Góry Atos, które sprawuje się w uroczystości Epifanii i Zesłania Ducha Świętego, następuje taka chwila, gdy zostają zapalone wszystkie światła: zarówno te z sufitu jak i z centralnej korony. Następnie zaczyna się kołysać pierwsze nich, podczas gdy wiruje wielkie korona wokół własnej osi. Taniec świateł trwa przynajmniej godzinę aż wszystko powoli się zatrzyma. Drżenie tysiąca płomieni, błysk złota, stukanie metali, zmiana kolorów w ikonach, śpiewy chóru, który towarzyszy tym galaktykom gwiazd poruszających się niczym sfery niebieskie... wszystko to jest jakby przybliżeniem się do tajemnic nieba.

Jest bardzo prawdopodobne, że chociaż Jezus nie powiedziałby „,ja jestem światem świata", chrześcijanie dostrzegliby w świetle słońca symbol Zbawiciela. Wejście do pomieszczenia, w którym sprawuje się ryt eucharystii słabo oświetlonej byłoby doświadczeniem odrzucającym, ponieważ wejście w liturgię oznacza zanurzenie się in lucem sanctam ${ }^{26}$. Nie jest to jakiekolwiek światło, lecz światło zwyciężające nad ciemnością,

${ }^{24}$ Wyrażenie to pochodzi z poematu napisanego w 1934 roku, zatytułowanego "Chóry skalne".

${ }^{25}$ Por. Peregrinatio Egerić, 24, 4; por. E. Kapellari, I santi segni della liturgia, Cinisello Balsamo (Milano): San Paolo 1991, s. 48.

${ }^{26}$ Hymn nieszporów ze święta Ofiarowania Pańskiego (2 lutego) określa niebo jako aula lucis. 
ponieważ „Chrystus jest «światłem na oświecenie pogan», którym świeci Kościół i przez niego cała rodzina ludzka"27. Procesyjne wejście usługujących w liturgii, z towarzyszeniem śpiewu na wejście, dokonuje się przez nawę będącą koniecznie dobrze oświetloną, ponieważ gdy sprawuje się świętą liturgię budynek kościoła jest domem światła. Procesja dociera do sanktuarium i kilka zapalonych świec wskazuje na święto, które otacza ołtarz, na którym aktualizuje się paschalne przejście Chrystusa. Promieniują światłem także uczestnicy Wieczerzy Pańskiej.

Do miana tego, co tak cudownie wyrazili architekci kościołów bizantyjskich w Rawennie, dla których nawa prowadziła ludzi z ziemi do nieba, a sanktuarium było rajem, mogłaby pretendować technika oświetlenia współczesnych kościołów ${ }^{28}$. Mądre dysponowanie iluminacją może stworzyć piękne efekty, gdy skupi się na pewnych punktach, jak na przykład, na skrzyni z relikwiarzami znajdującej się pod ołtarzem czy wspaniałych relikwiarzach w dniu pierwszego listopada.

\subsection{WITRAŻE}

Światło budynku kultycznego nie jest zwykłym światłem monochromatycznym. Światło, które przepełnia przestrzeń liturgiczną może być postrzegane poprzez elokwentne i pełne symbolizmu pośrednictwo witraży, świata zbudowanego z rzeszy kolorowych szkieł, zdolnych do wyrażenia w jaki sposób niebieskie Jeruzalem, zakotwiczone poza czasem, może ponownie wyrazić się w "architektonicznym Taborze”.

Witraże oferują wiele odcieni kolorów w ciągu dnia, w zależności od natężenia promieni słonecznych i ich kąta padania. Poprzez ten efekt przestrzeń otrzymuje niezmierną zdolność komunikacji. Można powiedzieć, że światło naturalne, przeszedłszy przez filtr witrażu, przelewa w czas iskry wieczności, czyniąc dotykalnym (dzięki swemu kolorowemu światu) blask niebieskiego Jeruzalem. W istocie jest czymś innym spoglądać na witraże stojąc na zewnątrz katedry niż z jej wnętrza, pod światło. W pierwszym przypadku widać jedynie ciemne kawałki szkła, złączone ołowianymi spoiwami - również ciemnymi; w drugim przypad$\mathrm{ku}$, to znaczy kontemplując witraż z wnętrza katedry, wzrok odkrywa pełną panoramę kolorów i kształtów, które wyrażają zdumienie wobec

\footnotetext{
${ }^{27}$ Por. Ordo dedicationis ecclesice et altaris, 22d.

${ }^{28}$ Por. J. Plazaola, Arte sacro actual, Madrid: BAC, 2006, s. 187-192.
} 
tajemnic Chrystusa. Każdy, kto odwiedził katedrę w Chartres mógł tego doświadczyć. Począwszy od zimna niebieskich kolorów, dominującego w północnej stronie świątyni, aż po ciepłą kolorystykę południowych witraży, wszystko pomaga w przylgnięciu do Misterium, które postrzega się jako bliskie. Ten efekt zbliżania ziemi z niebem wyjaśnia sukces witraży, porównywanych przez niektórych autorów nawet z księgami Pisma Świętego i z Apostołami, ze względu na ich funkcję strzeżenia i oświecania wiernych ${ }^{29}$.

\section{5. ŚWIATKA W EUCHARYSTII}

Znaczenie symboli w liturgii nie jest arbitralne. Ogólne Wprowadzenie do Mszału wyjaśnia znaczenie świateł w czasie Mszy św.: zapalone świecie są „wyrazem szacunku i uroczystego charakteru celebracji”. "Na czas każdej celebracji stawia się przynajmniej dwa świeczniki z zapalonymi świecami; może ich być więcej: cztery lub sześć, zwłaszcza w niedzielę albo obowiązujące święto, lub, gdy celebruje biskup diecezjalny, siedem"30. Początki liczby siedmiu świec sięgają starożytności. To w Ordo Romanus I (VII w.) spotykamy pierwsze świadectwo dotyczące światła. Opisując liturgię stacyjną sprawowaną przez biskupa Rzymu, Ordo ustanawia, że wśród posługujących towarzyszących papieżowi od zakrystii aż do ołtarza znajduje się siedmiu akolitów, z których każdy niesie przed papieżem zapaloną świecę. Gdy dotrą do ołtarza stawiają świeczniki na ziemi, cztery po prawej i trzy po lewej stronie, które pozostają zapalone aż do końca celebracji ${ }^{31}$.

Zastosowanie światła w liturgii chrześcijańskiej mogłoby być reminiscencją norm, które protokół rzymski przewidywał dla sędziów, którzy wchodząc na salę rozpraw byli poprzedzani przez sługi trzymających zapalone pochodnie i urzędnika niosącego Liber mandatorum, to znaczy kodeks. Księgę kładziono na stole przed sędzią, a po obu stronach stawiano zapalone świeczniki. W ikonografii chrześcijańskiej obecność zapalonych świec w scenie przedstawionej na mozaice czy też grobie

${ }^{29}$ Por. S. B. Tosatti, Vetrata, w: Nuovo dizionario patristico e di antichità cristiane, vol. 2, Genova-Milano: Marietti, 2006-2008, s. 1398-1399.

${ }^{30}$ Por. Ordenación General del Misal Romano (2002), s. 117 i 307.

${ }^{31}$ Por. Ordo Romanus I (ed. M. Andrieu, Louvain 1931-1961), 49 oraz Cćremoniale Episcoporum, n. 125c. Znaczenie siedmiu świec można rozpatrywać w odniesieniu do pełni kapłaństwa właściwego biskupowi. 
może być sposobem na podkreślenie, że dana scena rozgrywa się nie na ziemi, lecz w niebie ${ }^{32}$.

\subsection{KOD CHROMATYCZNY LITURGII}

Na początku Bóg stworzył światło. Dlatego świat może zostać zrozumiały jedynie w świetle. Człowiek nie może jednak na nie spoglądać bezpośrednio, a będąc nieogarnionym dla siatkówki oka, źródło światła znajduje się „poza”. Tym, co pozostaje dostępne są kolory. Gdy ustępują ciemności i zaczynają przedzierać się pierwsze promienie poranka, dopiero wówczas zdają się pojawiać kolory. Podczas, gdy zwierzęta, nawet zwierzęta wyższe jak koń czy pies, widzą na biało i czarno, człowiek posiada przywilej postrzegania kolorów. Dla człowieka kolor jest dotykiem oka.

Kolory nie są cyframi pewnego kodeksu ezoterycznego; wyrażają lub prowokują stany duszy, podobnie do sposobu, w jaki czyni to muzyka. Kolory są muzyką oczuㄹ. Michał Anioł przywiązywał taką wagę do koloru w Kaplicy Sykstyńskiej, że nie rozpoczął malowania fresku aż nie otrzymał koloru niebieskiego, lazurytu pochodzącego z Persji. Znawcy często odnoszą się do koloru „niebieskiego” Michała Anioła.

Moglibyśmy powiedzieć, naprężając nieco słowa, że kolory odpowiadają pewnej logice, która w pewnym sensie jest „logiką sakramentalną": Misterium światła wyraża się poprzez kolory i kolory są świadkami światła. Całą ziemię napełnił mrok około trzeciej popołudniu w Wielki Piątek, przywdziewając kolory wyrażające płacz światła. W niedzielny zaś poranek doświadczenie światła stało się świętem kolorów.

Nie wszystko jest jednak proste i jasne w historii kolorów liturgicznych $^{34}$. Amalariusz z Metz († 850) nie odnosi się do nich, ponieważ w jego epoce ledwo były rozróżniane. Nie znamy kolorystyki, którą stosowano w rycie hiszpańsko-mozarabskim, jeśli istniała przynajmniej od pewnego etapu jego ewolucji historycznej. Zmiany kolorów w ubiorach liturgicznych wyrażają dynamikę boskich Tajemnic sprawowanych w tym meta-werbalnym kodzie. Dlatego przejście z koloru fioletowego,

32 Por. F. Cabrol, Cierges, w: Dictionnaire d'Archéologie chrétienne et de Liturgie, 3/2, Paris: Letouzey et Ané, 1907-1953, s. 1618.

${ }^{33}$ Por. P. Miquel, La liturgia, una obra de arte, Zamora: Monte Casino 1996, s. 87.

${ }^{34}$ Por. C. Noonan, The Church visible - The ceremonial life and protocol of the Roman Catholic Church, Viking Press, New York 1996. 
dominującego w Wielkim Poście, do radosnej bieli w święto Paschy, aby zwieńczyć całość czerwienią Ducha Świętego w święto Zesłania, wydaje się przejściem dydaktycznym. Proklamowane Słowo Boże, wypowiadane modlitwy, intonowane śpiewy... wszystko to wyraża na swój sposób sprawowane Misterium, nie uciekając od koloru, który niesie z sobą skuteczną pedagogię. Z drugiej strony kanon chromatyczny rytu ambrozjańskiego różni się od rzymskiego: w kościele lokalnym Mediolanu, począwszy od pierwszych niedzieli Paschy aż do wigilii Zesłania Ducha Świętego, zamiast koloru białego, stosuje się kolor zielony; a we wszystkie niedziele i dni zwykłe po Zesłaniu stosuje się kolor czerwony zamiast zielonego.

\subsection{CZERWONY I NIEBIESKI PANTOKRATOR}

W pismach św. Pawła odkrywany swoisty Weltanschauung, w którym serce kosmosu stanowi boskie człowieczeństwo Chrystusa, który łączy to, co ludzkie z tym, co boskie, stworzone i niestworzone. Światło szczególnie wyróżnia w tym sercu dwa intensywne kolory: czerwony i niebieski. Są to dwa kolory, w których chrześcijanin pierwszego tysiąclecia rozpoznawał to, co boskie i to, co ludzkie. Sztuka bizantyjska posługuje się kolorem czerwonym i niebieskim do namalowania teantropicznych ubrań Pantokratora.

Rozmiary architektoniczne, oświetlenie otoczenia, obrazy, witraże... i wiele innych elementów z bogatego języka symbolicznego zatapiają się w liturgii w obecność kolorów, aby zbudować czółno, które doprowadzi ducha do okolic tego, co niewypowiadalne, gdzie chrześcijanin może doświadczyć tajemnicy piękna Boga. W metaforycznym stwierdzeniu Pawła Floreńskiego († 1937), rozważającego teologię ikon, kolory są boską obecnością, które się do nas zbliżają, aby mogły być kontemplowane przez oczy naszego odkupionego serca. Poprzez tę pedagogię kolor staje się głosem Słowa, ponieważ według Teodora Studyty († ok. 826) to, co wyrażone zostało na papierze, pojawia się także wypisane kolorami ikony ${ }^{35}$.

Dla uczestniczącego w celebracjach liturgicznych kolory nie tylko pojawiają się na ikonach, lecz także na witrażach, w ubiorach, w kwiatach, w ozdobach umieszczonych na paschale, w perłach Ewangeliarza

${ }^{35}$ Por. Teodoro Studita, Antirrhetica adversus iconomachos I, 10, PG 99, 340. 
oprawionego w srebro i kość słoniową, w rycinach i ilustracjach znajdujących się na jego stronicach. Istnieje wiele takich "słów” w języku liturgicznym (meta-werbalnym), które łącząc się z językiem werbalnym, pozwalają na przeżycie Wydarzenia zbawczego, które przemienia i przebóstwia człowieka.

\section{LITURGY AND POSTMODERNISM: IN PERSPECTIVE AT THE 50TH ANNIVERSARY OF II VATICAN'S COUNCIL}

\section{ABSTRACT}

The discourse of liturgical theology, situated in the conjunction between sacredness and anthropology, may facilitate the announcement of the kerygma in the coordinates of comprehension that post-modernity requires. The author deals with the question of the Mystery and its symbolization from the perspective of Christ Jesus who, as the visibility of God's beauty, makes transparent the splendor of the divinity in the sensible experience of humanity. Among the symbolic languages that take part in the liturgical celebration, light vigorously impresses the architect. The architect generates creative solutions for the areas of celebration, in the same way that, in older times, the orientation of rosettes and stained glass windows demanded the medieval master mason's attention.

\section{LITURGIA Y POSTMODERNIDAD A LAS PUERTAS DEL 50 ANIVERSARIO DEL CONCILIO VATICANO II}

El discurso de la teología litúrgica, situado en la conjunción entre sacralidad y antropología, puede impulsar un anuncio del kerygma en las coordenadas de comprensión que la postmodernidad requiere. El autor expone la cuestión del Misterio y su simbolización desde la perspectiva de Cristo Jesús que, siendo la visibilidad de la belleza de Dios, ha transparentado el esplendor de la divinidad en la experiencia sensible de la humanidad. Entre los lenguajes simbólicos que intervienen en la celebración litúrgica, la luz interpela vigorosamente al arquitecto. Éste genera soluciones creativas para los espacios celebrativos, como en otro tiempo la orientación de rosetones y vidrieras demandaron la atención del maestro de obra medieval. 